\title{
Disability benefit growth and disability reform in the US: lessons from other OECD nations
}

\author{
Richard V Burkhauser ${ }^{1}$, Mary C Daly ${ }^{2 *}$, Duncan McVicar ${ }^{3}$ and Roger Wilkins ${ }^{4}$
}

\author{
* Correspondence: \\ mary.daly@sf.frb.org \\ ${ }^{2}$ Federal Reserve Bank of San \\ Francisco, San Francisco, USA \\ Full list of author information is \\ available at the end of the article
}

\begin{abstract}
Unsustainable growth in program costs and beneficiaries, together with a growing recognition that even people with severe impairments can work, led to fundamental disability policy reforms in the Netherlands, Sweden, and Great Britain. In Australia, rapid growth in disability recipiency led to more modest reforms. Here we describe the factors driving unsustainable DI program growth in the U.S., show their similarity to the factors that led to unsustainable growth in these other four OECD countries, and discuss the reforms each country implemented to regain control over their cash transfer disability program. Although each country took a unique path to making and implementing fundamental reforms, shared lessons emerge from their experiences.

JEL codes: $J 14, J 18$

Keywords: Disability; Cross-national policy; Social Security Disability Insurance
\end{abstract}

\section{Introduction}

Unsustainable growth in program costs and beneficiaries, together with a growing recognition that even people with severe impairments can work, led to fundamental disability policy reforms in the Netherlands, Sweden, and Great Britain. These fundamental reforms substantially reduced disability recipiency rates in these nations and put their disability programs back on a sustainable fiscal footing. For the most part the reforms focused on slowing entry onto long-term disability cash transfers by keeping newly impaired workers in the labor market. Although there were some efforts to reduce the number of existing beneficiaries through disability reassessments and work incentives, these were both less important and less successful. In Australia, rapid growth in disability recipiency led to more modest reforms; disability recipiency rates have fallen slightly in response, but there are reasons to believe the system remains vulnerable to a resurgence in growth.

The United States is now considering how best to reform its primary long-term disability cash transfer program, Social Security Disability Insurance (DI). As was the case in Australia, the Netherlands, Sweden, and Great Britain before their reforms, disability recipiency in the U.S. is rising at an unsustainable pace. The DI rolls have risen from 1.2 million in 1967 to 8.8 million in 2012, and since 2009, the DI program has been paying out more in annual benefits than it receives in taxes and interest from its trust fund. Based on current growth, the DI program is projected to be insolvent by 2016 (Social Security Administration 2013a). At issue is whether modest reforms that adjust aspects of the existing program or more fundamental reforms that change how disability is identified and supported will be necessary to resolve these problems.

(c) 2014 Burkhauser et al.; licensee Springer. This is an Open Access article distributed under the terms of the Creative Commons Attribution License (http://creativecommons.org/licenses/by/2.0), which permits unrestricted use, distribution, and reproduction in any medium, provided the original work is properly cited. 
Here we describe the factors driving unsustainable DI program growth in the U.S., show their similarity to the factors that led to unsustainable growth in these other four OECD countries, and discuss the reforms each country implemented to regain control over their cash transfer disability program. Although each country took a unique path to making and implementing fundamental reforms, shared lessons emerge from their experiences.

First among them is that disability is not an immutable state, but rather a product of health and the social, cultural, and economic environment faced by individuals with impairments. This leads to the second lesson: disability policy itself affects the behavior of individuals with impairments. As reforms in these countries demonstrate, generous programs conditioned on not working lead to lower levels of work and higher disability recipiency than programs focused on maintaining individuals with impairments in the labor market.

The third lesson is that incentivizing individuals with impairments to stay in the labor market is far easier than incentivizing existing disability beneficiaries to return to work. This means that gaining control of disability rolls is best done by stemming the flow of new beneficiaries rather than trying to reduce existing DI caseloads. Finally, a recurring theme in each of the countries undertaking fundamental reforms is that disability policy is part of the broader social safety net and cannot be altered independently. As the experiences of these OECD nations demonstrate, attempts to alter disability programs without acknowledging that they interconnect with unemployment, retirement, and general social welfare programs and vice versa can result in unintended changes in program use and unsustainable growth in program rolls.

\section{Disability program growth across countries}

The number of workers receiving social insurance for disability has increased substantially in most OECD nations over the past forty years. Population growth explains part of this increase, but disability caseloads as a share of the working age population ageknown as the disability recipiency rate-also have risen rapidly ${ }^{1}$. This can be seen in Figure 1, which shows the total number of persons receiving long-term categorical disability income benefits as a share of the working-age population in the United States and four other OECD countries ${ }^{2}$. This is the number most critical to policymakers since it measures the magnitude of the fiscal burden that these disability programs place on country finances ${ }^{3}$. We show values beginning in 1970 through the last year these data were made public in each country ${ }^{4}$. A more detailed description of the data for each country is provided in Additional file 1: Appendix A.

The figure plots the level of disability recipiency (disability beneficiaries as a share of the working-age population) over time for each country. In 1970, disability recipiency rates in our three European nations were considerably higher: 3.5 percent in Sweden, 2.8 percent in Great Britain (1971) and 2.4 percent in the Netherlands, than they were in Australia (1.6 percent) and the U.S. (1.2 percent). Since then disability recipiency rates have risen substantially in each country, although as the figure highlights, they have done so along significantly different trajectories.

To see these fluctuations more clearly, Table 1 provides average annual growth rates in disability recipiency by decade and over the entire sample. As the table shows, disability recipiency rates rose in all countries during the 1970s, with especially rapid growth in the Netherlands. In the 1980s, each country gained some control over their 


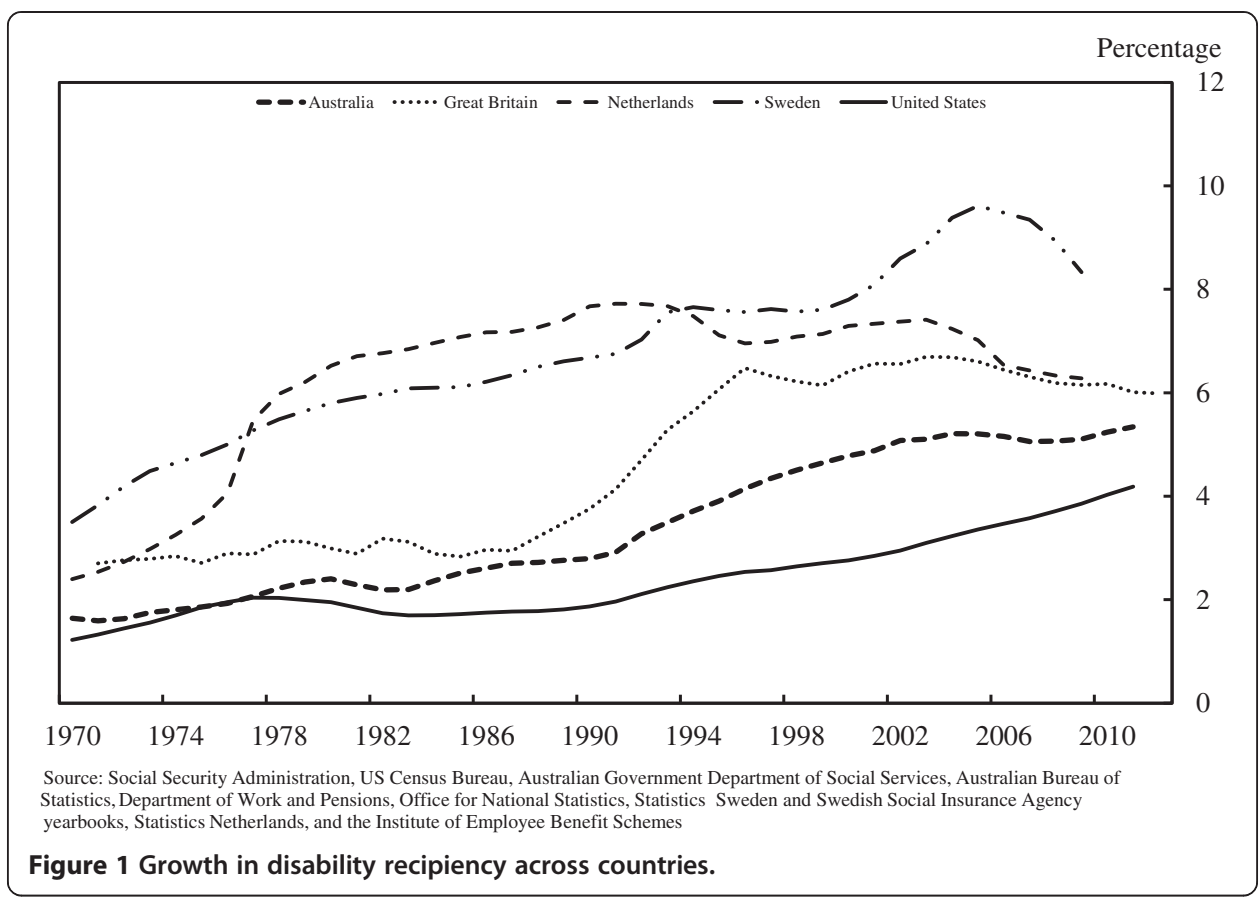

disability programs. Recipiency rates grew more modestly and even fell in the U.S. By the 1990s, growth in the Netherlands ended and disability recipiency rates fell on balance over the decade. In the other countries, rates increased, with Great Britain posting the fastest pace of growth. During the 2000s, disability recipiency rates continued to come down in the Netherlands and either plateaued (Australia) or fell (Sweden and Great Britain) in all countries but the U.S.

The final average (1970-final) shows that smoothing through the fluctuations in growth that have occurred over the decades, the U.S. has experienced the highest average annual growth rate over the sample period. This is because periods of unsustainable growth in other countries were followed by program reforms that tempered or reversed the path of disability recipiency and allowed countries to regain control of program growth. In contrast, with the exception of the 1980s, growth in U.S. disability recipiency has been nearly continuous over the sample period.

Of course one possible explanation for the differences in growth across countries is that health and population characteristics have evolved differently for each nation over

Table 1 Average annual growth in disability recipiency by decade and Country ${ }^{1,2}$

\begin{tabular}{lccccc}
\hline & Australia & Great Britain & Netherlands & Sweden & United States \\
\hline $\mathbf{1 9 7 0 - 1 9 7 9}$ & 4.09 & 1.89 & 11.45 & 5.49 & 5.65 \\
$\mathbf{1 9 8 0 - 1 9 8 9}$ & 1.73 & 1.27 & 1.79 & 1.59 & -0.91 \\
$\mathbf{1 9 9 0 - 1 9 9 9}$ & 5.37 & 5.99 & -0.34 & 1.44 & 4.10 \\
$\mathbf{2 0 0 0}-$ Final & 1.18 & -0.18 & -1.25 & 1.00 & 3.71 \\
$\mathbf{1 9 7 0}-$ Final & 2.98 & 2.08 & 2.69 & 2.30 & 3.10 \\
\hline
\end{tabular}

Source: Social Security Administration, US Census Bureau, Australian Government Department of Social Services, Australian Bureau of Statistics, Department of Work and Pensions, Office for National Statistics, Statistics Sweden and Swedish Social Insurance Agency yearbooks, Statistics Netherlands, and the Institute of Employee Benefit Schemes. 1.) See Additional file 1 for a summary of data years utilized across countries. 2.) Average is computed as the average year over year percent change in the recipiency rate within the given time period. For missing data a standard linear interpolation is used. 
time. If this is the case, then U.S. policymakers might find little guidance in the reforms of other nations. For example, if health or population characteristics are driving growth in the U.S. disability rolls, rather than disability policy and its implementation, then the fundamental restructuring of disability policy undertaken in other nations may not be warranted or successful in the U.S.

To understand the extent to which these factors might explain the growth in disability recipiency shown in Figure 1 and Table 1, we compare trends in self-reported health across countries and more formally evaluate the role that demographics and other changes in the population eligible for disability benefits might have in impacting trends in disability recipiency rates. We begin by examining trends in self-reported health over time and across countries. Figure 2 reports data from the OECD on self-reported health status for each of our countries. The plot shows the percentage of the population in each country reporting that they are in good health on a survey that asks respondents to state whether they are in good, fair, or poor health.

Although there are persistent differences across countries in the percent of individuals reporting good health, there is little variation over time within countries ${ }^{5}$. Over the past ten years the overall prevalence of good health among working-age populations has remained relatively steady in each country. The relative stability of the health measure in each of our sample countries suggests that changes in the prevalence of disabilities in the working-age population is unlikely to be responsible for the within and across country fluctuations in disability recipiency rates found in Figure 1 and Table 1.

A second reason disability recipiency rates may have varied across countries over time is that the eligible populations in those nations may have evolved differently. To investigate this possible explanation, we compute counterfactual disability recipiency rates for each country using the methodology in Daly et al. (2013). This measure represents the growth in disability recipiency rates, absent the influences of the aging of the

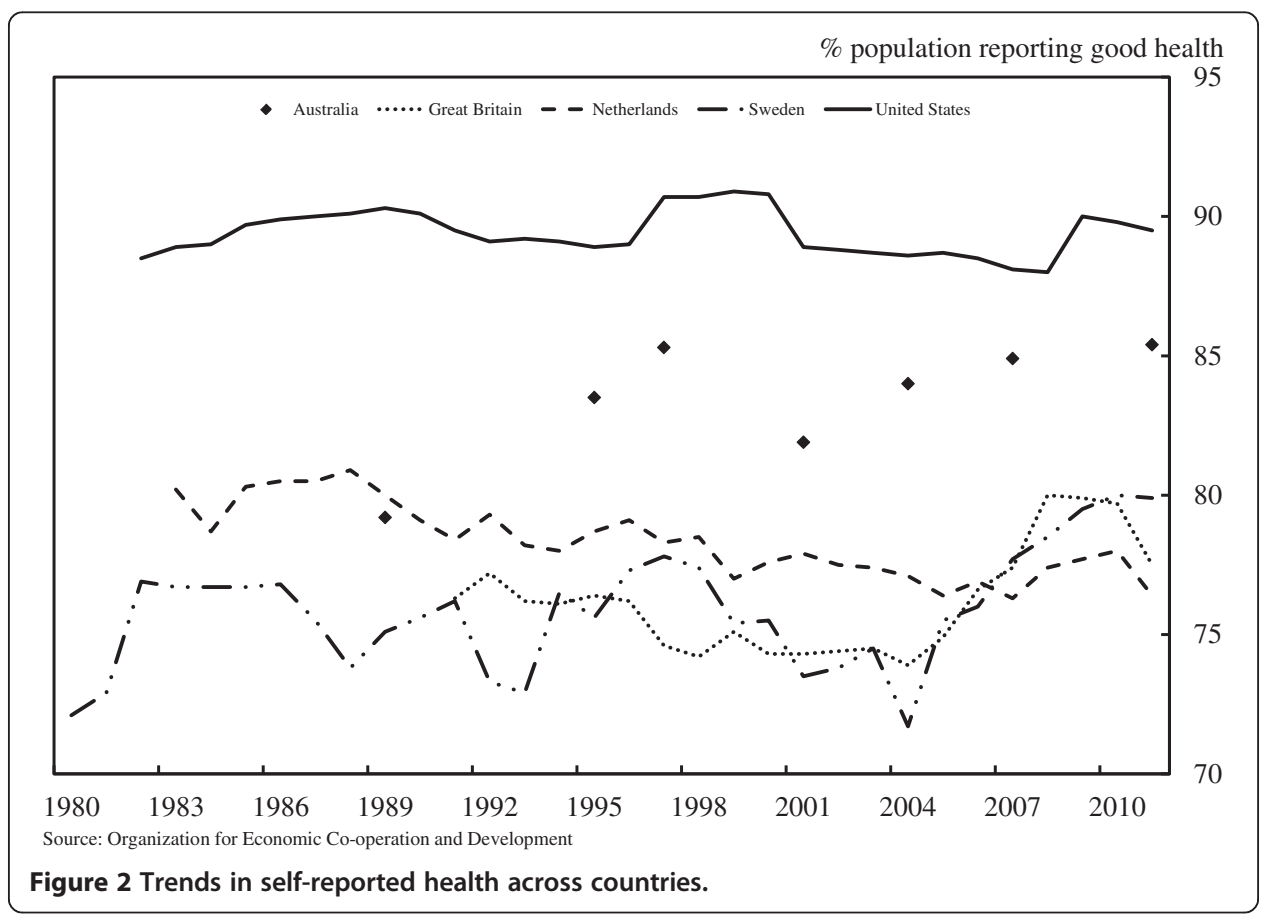


workforce and any increase in eligibility age for retirement benefits. In addition, in the U. S., we also consider the rise in the employment rate of women and associated increase in DI coverage (to be eligible for DI you must have worked at least 5 of the last 10 years) which have changed over this period. The details of these calculations and the specific factors we control for in each country are provided in Additional file 1: Appendix B.

Figure 3 (panels A through E), plot the actual (the same rates shown in Figure 1) and adjusted disability recipiency rates, that net out these demographic and eligibility factors, for each country over time. The gray bars in the figures reflect recession periods in each country. The figures also include information about key policy changes in each country; we will refer back to these in the next section when we summarize the evolution of policy in each country.

The panels in the figure show that changes in the composition of the eligible population have been more important in some countries than in others. For example, changes in the eligible population had a notable effect in the U.S. and Australia whose postWorld War II baby boom generations were large. As these populations aged, they put notable pressure on disability recipiency rates in the 1990s and 2000s. This was not the

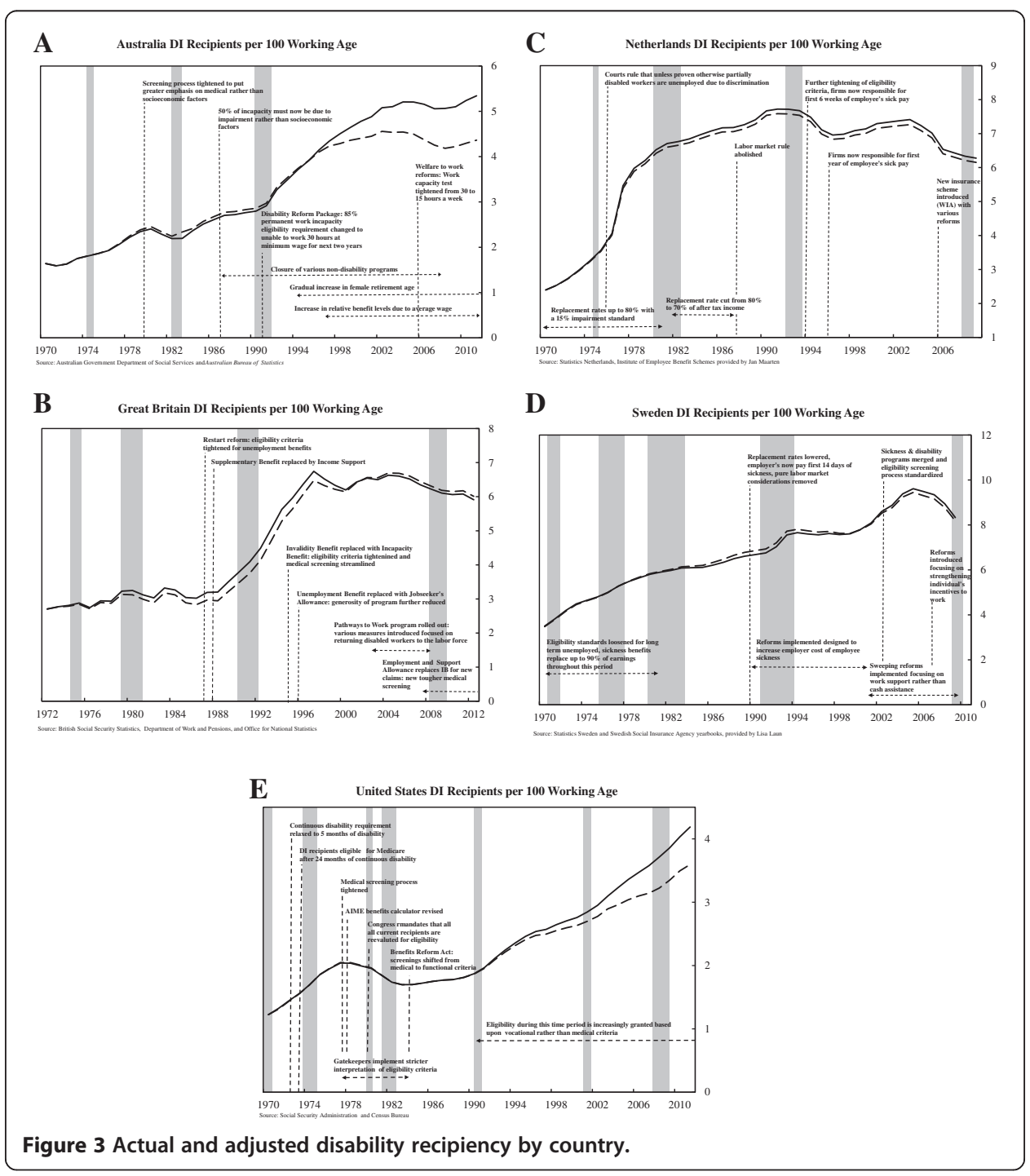


case in the three European countries, where adjustments for demographic changes make almost no difference to the path of disability recipiency rates.

Overall, accounting for these changes does little to alter the picture developed in Figure 1 and Table 1. This is confirmed in Additional file 1: Appendix B which repeat the analysis in Figure 1 and Table 1 using the adjusted disability recipiency rates. Additional file 1: Appendix B shows that controlling for these population factors, it remains the case that over the entire sample period a higher share of working-age people are on categorical disability cash transfers in the Netherlands, Sweden and Great Britain than in the U.S. and Australia. Additional file 1: Appendix B shows that over the past 40 years, the U.S. has had the highest average growth rate. Thus, even when we adjust for differences in population characteristics across countries, the U.S. remains an outlier in experiencing ongoing growth in disability recipiency rates ${ }^{6}$. Since to date no major policy reforms have been implemented to address this growth, this gap between the U.S. and these other countries is likely to grow larger in coming years.

The finding that neither health nor population characteristics can explain the crosscountry differences in disability recipiency rates, either levels or trends, underscores the potential role for policy ${ }^{7}$. In what follows we describe how changes in disability policy and its implementation in each country account for the fluctuations in the growth of these disability recipiency rates.

\section{Disability policy and program growth}

In industrialized nations, social protection from income loss associated with disability is just one part of a broader social safety net designed to protect working age individuals from the loss of labor market income. Since labor market work is the primary source of income for most families, OECD nations generally have built complex social protection schemes designed to support individuals who are unable to earn wages in the labor market. Most countries provide this protection in tiers associated with the social expectations for employment of different groups.

In general, the first tier provides universal, long-term, needs-based cash transfers that guarantee a social minimum income to all families. The second tier provides cash support to those available for employment and expected to work, but who are temporarily unemployed. These benefits are usually conditional on past work, limited in duration, and may be needs-based. The third tier targets benefits to those not expected to work - the aged, disabled, etc.-and can either be needs-based or based on past earnings. Since recipients of these benefits are not expected to return to employment, benefits are typically higher and not time limited.

When these tiers provide substantially different amounts of income and their categories are mutable, it is critical that the long-term or higher benefit programs have verifiable eligibility criteria that allow program gatekeepers to consistently determine who should come onto the program. For retirement programs this is straightforward; age is an arbitrary but easily verifiable eligibility marker. Eligibility determinations by program gatekeepers will not vary greatly over the business cycle and forecasts of program growth will be relatively easy to make.

Disability is more difficult. Unlike retirement, there is no precise definition or easily verifiable marker for determining categorical eligibility for long-term disability benefits. Moreover, disability is not a static concept and social conceptualizations of disability 
evolve over time. For example, over the last 20 years the medical model of disability underlying categorical disability programs in most OECD countries has been rejected and replaced by a conceptualization that recognizes that the social environment is as important as health in determining an individual's ability to participate in society (World Health Organization 2001) ${ }^{8}$. Under this model, "work disability" is a changeable state that depends on a number of factors, including an individual's health impairment, the level of accommodation offered in the workplace, and the relative economic payoffs associated with working or exiting the labor force to receive disability benefits.

The fluid nature of the disability category has meant that changes to disability policy parameters such as the level of benefits and the scope of conditions that qualify have had much larger impacts on caseload growth and disability recipiency rates than policymakers expected or even intended. For the most part, the unanticipated effects can be traced back to the interplay between disability programs and the policy and economic environment within which they operate.

For example, in a number of OECD nations, the relative value of disability benefits has risen significantly over time, as policymakers have cut payments or imposed stricter eligibility criteria on other benefit programs including unemployment insurance and general welfare. Structural changes in the economy including the declining job and wage prospects for low-skilled workers also have made disability benefits more attractive as means of long-term income support. Finally, disability benefits have increasingly become an option for displaced or long-term unemployed workers dislocated during economic downturns. Since very few disability beneficiaries ever return to the labor market, the growth in the rolls that occurs during and after recessions leads to a long term increase in disability recipiency rates. These rates then remain elevated until these recession induced cohorts of beneficiaries age out of the system or die. For a more detailed discussion of these issues in OECD nations see Organization for Economic Co-operation and Development (2010).

Below we discuss how disability program designs and changes in disability policy parameters in Australia, Great Britain, the Netherlands, Sweden, and the U.S. have affected disability recipiency rates in each country. When relevant we also discuss how these policy structures have interacted with macroeconomic conditions and the broader social safety net to amplify growth in the disability rolls. For reference, Figure 3 (Panels A through E) shows disability recipiency rates (unadjusted and adjusted) along with major policy changes over time for each country. Table 2 provides key information about the current state of disability programs in each nation.

\subsection{The US experience}

The United States has no first-tier, universal needs-based cash transfer program that provides a guaranteed social minimum income floor to all its citizens. The Supplemental Security Income (SSI) program, which is limited to the aged, disabled adults and parents of disabled children, is its only long-term needs-based cash transfer program ${ }^{9,10}$. The only other major categorical needs-based cash transfer program in the U.S. is Temporary Assistance for Needy Families (TANF), which is targeted at single mothers and provides an even lower guaranteed income level and the guarantee is limited to 5 years. 


\begin{tabular}{|c|c|c|c|c|c|}
\hline & Australia & Great Britain & Netherlands & Sweden & United States \\
\hline $\begin{array}{l}\text { Summary of } \\
\text { Benefits Program }\end{array}$ & $\begin{array}{l}\text { Universal means-tested flat-rate } \\
\text { benefit payable to people with dis- } \\
\text { ability aged } 16 \text { and over. }\end{array}$ & $\begin{array}{l}\text { Insurance-based flat-rate benefit } \\
\text { payable to people with disability } \\
\text { with sufficient work history; same } \\
\text { flat-rate benefit payable to people } \\
\text { with disability with insufficient work } \\
\text { history, but means-tested }\end{array}$ & $\begin{array}{l}\text { Merged sickness and disability } \\
\text { program which makes a strict } \\
\text { distinction between fully and } \\
\text { partially disabled. Those fully } \\
\text { disabled receive guaranteed } \\
\text { income until age } 65 \text { while partially } \\
\text { disabled workers receive benefits } \\
\text { conditional on work history and } \\
\text { incapacity level determined by } \\
\text { doctor. }\end{array}$ & $\begin{array}{l}\text { Merged sickness and disability } \\
\text { system with disability benefits } \\
\text { granted only to those deemed to } \\
\text { have permanent reductions in work } \\
\text { capacity. }\end{array}$ & $\begin{array}{l}\text { Social insurance } \\
\text { program for workers } \\
\text { who have paid social } \\
\text { security taxes over their } \\
\text { working lives with } \\
\text { benefit levels tied to } \\
\text { past earnings. }\end{array}$ \\
\hline $\begin{array}{l}\text { Full or Partial } \\
\text { Benefits Program }\end{array}$ & $\begin{array}{l}\text { Intended to cover only individuals } \\
\text { incapable of at least } 15 \text { hours per } \\
\text { week of gainful employment. }\end{array}$ & $\begin{array}{l}\text { Intended to cover individuals with } \\
\text { very limited capacity to work, so } \\
\text { closer to a full disability program } \\
\text { than a partial disability program. } \\
\text { But not restricted to permanent } \\
\text { disability. }\end{array}$ & $\begin{array}{l}\text { Program differentiates between full } \\
\text { (IVA) and partial disability (WGA) } \\
\text { and awards benefits accordingly } \\
\text { (see above). }\end{array}$ & $\begin{array}{l}\text { Workers may receive sickness } \\
\text { benefits in the event of a sickness } \\
\text { (with approval of a doctor), } \\
\text { however disability insurance is only } \\
\text { granted to those with a serious } \\
\text { and permanent impairment that } \\
\text { reduces work ability. }\end{array}$ & $\begin{array}{l}\text { Full disability program } \\
\text { designed to be a last } \\
\text { resort program for those } \\
\text { with permanent and } \\
\text { total disabilities. }\end{array}$ \\
\hline Eligibility Criteria & $\begin{array}{l}\text { Must have a physical, intellectual or } \\
\text { psychiatric impairment which has a } \\
\text { severe (or extreme) functional } \\
\text { impact, and must be unable to } \\
\text { work at least } 15 \text { hours per week in } \\
\text { a minimum-wage job for at least } \\
\text { (the next) two years. }\end{array}$ & $\begin{array}{l}\text { Must be assessed as having "limited } \\
\text { capacity to work", i.e. scoring } 15 \text { or } \\
\text { more points on a points-based as- } \\
\text { sessment of physical and mental } \\
\text { capabilities }\end{array}$ & $\begin{array}{l}\text { Applicants must meet with } \\
\text { designated doctor (either a } \\
\text { company doctor or agency) who } \\
\text { evaluate incapacity. Several } \\
\text { evaluations are carried out by } \\
\text { integration supervisors on a rolling } \\
\text { timeline during the initial two year } \\
\text { sickness period. }\end{array}$ & $\begin{array}{l}\text { Sickness benefits are awarded for } \\
\text { first } 14 \text { days with a doctors } \\
\text { approval and reevaluated along a } \\
\text { rolling timeline with worker "check- } \\
\text { ins". Disability benefits are only } \\
\text { awarded after the SIA determines } \\
\text { work capacity is permanently } \\
\text { reduced. }\end{array}$ & $\begin{array}{l}\text { Full disability program } \\
\text { requiring applicants to } \\
\text { be unable to perform } \\
\text { any substantial gainful } \\
\text { activity for at least one } \\
\text { year. }\end{array}$ \\
\hline $\begin{array}{l}\text { Benefits Conditional } \\
\text { on Contributions? }\end{array}$ & No. Benefits are universal. & $\begin{array}{l}\text { No, but more heavily means-tested } \\
\text { for those with insufficient contribu- } \\
\text { tions (insufficient work history) }\end{array}$ & $\begin{array}{l}\text { Yes. Benefits levels are conditional } \\
\text { on past earnings, number of weeks } \\
\text { worked before, and the percentage } \\
\text { of earnings the worker is deemed } \\
\text { capable of earning currently with } \\
\text { impairment. }\end{array}$ & $\begin{array}{l}\text { There are two types of benefits } \\
\text { awarded. A universally guaranteed } \\
\text { pension provides assistance to all } \\
\text { those residing in Sweden. The } \\
\text { earnings related pension is } \\
\text { contingent upon weeks of work }\end{array}$ & $\begin{array}{l}\text { Yes, sufficient quarters of } \\
\text { coverage necessary as } \\
\text { defined described in } \\
\text { Social Security } \\
\text { Administration 2013b. }\end{array}$ \\
\hline
\end{tabular}




\begin{tabular}{|c|c|c|c|c|c|}
\hline $\begin{array}{l}\text { Other Income } \\
\text { Programs for the } \\
\text { Disabled }\end{array}$ & $\begin{array}{l}\text { State workers' compensation } \\
\text { programs provide benefits for } \\
\text { workers injured on the job for up } \\
\text { to two years. Private disability } \\
\text { insurance policies also exist, } \\
\text { although commonly pay a single } \\
\text { lump sum for specified events } \\
\text { rather than an income stream. }\end{array}$ & $\begin{array}{l}\text { Statutory Sick Pay for first } 28 \text { weeks } \\
\text { for those in employment prior to } \\
\text { onset; a range of additional costs } \\
\text { benefits are potentially available in } \\
\text { addition to ESA (e.g. housing } \\
\text { benefit, Personal Independence } \\
\text { Payment) }\end{array}$ & $\begin{array}{l}\text { Means tested Social Assistance } \\
\text { Program (SA) with benefit equal to } \\
\text { minimum wage }\end{array}$ & $\begin{array}{l}\text { Assistance Allowance, Car } \\
\text { Allowance and other programs are } \\
\text { designed to accommodate those } \\
\text { who have severe, long-term disabil- } \\
\text { ities meeting specific criteria }\end{array}$ & $\begin{array}{l}\text { Workers Comp and SSI } \\
\text { and private disability } \\
\text { insurance }\end{array}$ \\
\hline
\end{tabular}


The second tier in the U.S. includes unemployment insurance benefits, which replace a fraction of wages for covered workers for short periods of time. In normal economic times, unemployment benefits can last up to 26 weeks. During recessions, this maximum is often extended and it rose to 99 weeks in the aftermath of the Global Financial Crisis. Unemployment insurance benefits are generally higher than SSI or TANF benefits.

The social security old-age retirement (OAI) and disability (DI) programs make up the third tier of benefits in the U.S.; they provide social insurance to workers who have paid social security taxes over their working life. To be eligible for benefits, workers must have accumulated sufficient quarters of coverage, as defined in the Social Security Administration's pension rules. These requirements are sufficiently strict to limit OAI and DI benefits to those with substantial attachments to the labor market. (For a summary of the benefit requirements and rules, see Social Security Administration 2013b.) Benefit levels from these programs are based on past earnings and can be substantially higher than the social minimum level of benefits guaranteed by the SSI aged and disability programs.

Eligibility for DI benefits requires applicants to meet a federal disability standard applied by administrative evaluators and adjudicators located in each state. The criteria are in principle quite strict. Eligibility requires that a worker be "unable to perform any substantial gainful activity on any job in the economy for at least one year". There is no benefit for partial disability. Disability benefits are intended to be a last-resort for those with permanent and total impairments. See Table 2 for more details on the U.S. DI program.

Although the written eligibility criteria have not changed over time, their implementation has and in a direction that has increased the number of working-aged adults receiving disability benefits. Indeed, many of the disability recipiency rate fluctuations shown in Figure 1 and Table 1 line up with changes in Social Security Administration (SSA) policy that made it easier or harder to gain entry to the DI rolls. For example, rapid disability recipiency rate growth in the 1970s aligns with Congressional actions that increased the replacement rate for a disabled worker with median earnings from 35 to 49 percent (Figure 3, Panel E). In the late 1970s and early 1980s disability recipiency rates fell, first because program gatekeepers were urged to more strictly interpret existing rules, and then because Congress in 1980 required SSA to reevaluate all current recipients to see if they still met the medical standards. This rule change, which was rigorously enforced by SSA at the start of the new Reagan administration, resulted in a drop in the DI rolls despite a major recession-the substantial drop in normalized adjusted disability recipiency rates in the U.S. between 1978 and 1983 are in stark contrast to the sizable growth in these values before 1978 and after 1990 (Figure 3, Panel E).

By 1983 the widespread reevaluation of those already on DI was halted as the courts and then Congress restricted the SSA's power to reevaluate beneficiaries. Furthermore, in 1984, responding to a backlash against restrictive cuts imposed in the Social Security Disability Amendments of 1980, policymakers expanded the ways in which a person could medically qualify for the DI program. The 1984 legislation moved away from a strict medical listing determination of eligibility to one that also considered an applicant's overall medical condition and ability to work. In addition, the legislation allowed for symptoms of mental illness and pain to be counted when 
assessing DI eligibility, regardless of whether the person had a verifiable medical diagnosis (Figure 3, Panel E) $^{11}$.

The expansion of eligibility to more difficult to measure impairments that do not precisely meet the medical listings means that SSA has increasingly been tasked with making more subjective decisions about the impact that presenting impairments might have on an applicant's work ability ${ }^{12}$. For applicants who do not meet or exceed the medical listings, program administrators consider a set of vocational criteria. While these vocational criteria have been in place over the history of the DI program, their use by program gatekeepers to determine benefit eligibility has risen dramatically since 1991. Currently, they are used to justify the majority of new awards, especially among those with the more difficult to determine conditions of mental illness and musculoskeletal conditions-the primary condition of more than 50 percent of all newly enrolled beneficiaries (Burkhauser and Daly 2011).

One consequence of expanding eligibility beyond identifiable medical listings is that DI applicants and gatekeepers have much more of a role in determining program growth. For example, over time the cyclical sensitivity of DI application rates has risen considerably. Applications rise during recessions and fall during periods of economic growth (see Rupp and Stapleton 1995; Stapleton et al. 1998; Black et al. 2002; Autor and Duggan 2003). But as can be seen in Figure 3, Panel E, increased applications generally result in an increase in disability recipiency rates which do not subside as economic conditions improve, since once on, very few beneficiaries ever leave the program.

In addition to the cyclical sensitivity of disability applications and awards, there is evidence that there has been a secular rise in the number of workers who apply over time related to the unintentional increase in the replacement rates of DI for low wage workers (Autor and Duggan 2003). Again, since few beneficiaries ever leave the rolls to return to work, the surge in disability recipient rates associated with business cycle fluctuations or economic restructuring has generally translated into a long-term increase in disability recipiency rate in the working age population.

Finally, there is evidence that the strictness of DI gatekeepers also varies. Maestas et al. (2013) using SSA administrative records estimate that 23 percent of applicants are initially accepted or denied based on whether they were assigned an easier or a stricter DDS gatekeeper rather than on differences in the status of their health or impairment status.

\subsection{The Netherlands ${ }^{13}$}

As in the U.S., the disability system in the Netherlands contains both a social insurance program that protects workers against lost labor earnings and a program that provides a social minimum for disabled adults with little or no work history. A separate social minimum scheme for the disabled self-employed ended in 2004. The Dutch social insurance program (WAO/WIA) provides cash transfers to working-age men and women based on lost labor earnings. The Netherlands does not have a separate program similar to Workers' Compensation. Rather, it has a longer-term disability transfer program that, together with the sickness benefits all private firms must offer their workers, provides a comprehensive system of both partial and total disability benefits to workers regardless of how or where their disability occurred. The Dutch also have a 
categorical disability-based welfare program (Wajong) that, unlike the general welfare scheme, is not means tested. This program is similar to the SSI-disabled adults program in that it targets men and women whose disabilities occurred prior to their entrance into the labor force and are severe enough that they have not engaged in full-time employment as adults. (See Table 2 for details of the disability program in the Netherlands.)

One reason for the rapid growth in the Dutch disability program over the 1970s was the relatively generous benefits that the system provided (Figure 3, Panel C). The first level of disability protection for Dutch workers was a universal sickness benefitessentially a universal short-term disability system. In the 1970s, government payments from this program replaced up to 80 percent of net-of-tax wage earnings for up to one year. However, most employees (90 percent) and all civil servants had the rest of their net-of-tax earnings replaced by collective-bargaining agreements with their employers. These disability replacement rates were far in excess of comparable programs in the U.S. Sickness benefits were payable for up to twelve months. After one year, employees still receiving benefits were eligible for disability benefit screening. Workers with chronic conditions that caused a reduction in their capacity to perform work commensurate with their job training and work history were eligible for disability benefits. Those judged fully disabled were eligible for benefits equal to 80 percent of their previous before-tax earnings. Those judged partially disabled (those with some residual earnings capacity) were eligible for partial benefits; the minimum degree of impairment for eligibility was 15 percent.

In a significant loosening of access to full disability benefits in the mid-1970s, Dutch courts determined that unless disability evaluators could prove otherwise, they were required to attribute a partially disabled worker's lack of employment to discriminatory behavior. The result was that it became "administrative practice" to treat unemployed, partially disabled persons as if they were fully disabled. That interpretation of the law made assessing lost earnings capacity unnecessary beyond the minimum 15 percent, since that became sufficient to entitle a person to full benefits. This essentially made the Dutch partial disability system a very generous full disability program. These increases in eligibility together with the generosity of the system in large part explain the 11.45 percent per year increase in adjusted Dutch disability recipiency rates seen in Table 1 and Figure 3, Panel C, during the 1970s.

The serious recession of the early 1980s and the growing costs of the disability system put pressure on the Dutch government to reduce the growth of disability-based transfers. Reforms initiated between 1982 and 1987 were the first of three major efforts over the next two decades to regain control of the Dutch disability transfer system. By 1985 , a series of cuts in the replacement rate effectively lowered it from 80 percent of before-tax income to 70 percent of after-tax income for both new entrants and current beneficiaries. But that did not halt system growth completely and in 1987 the labor market consideration rule was abolished. Despite the legal ban on including labormarket considerations in their assessments, disability adjudicators still tended either to grant or deny full benefits. Denial rates remained quite low, suggesting that the legal change did not stop the de facto use of labor-market considerations in the adjudication process. Nonetheless these changes are responsible for the slower growth in disability recipiency in the 1980s that brought the Netherlands more in line with disability growth in Sweden and Great Britain. 
But it was not until the 1994 reforms that disability recipiency rates began to drop. These reforms included further tightening of eligibility criteria. Additionally, in a new policy, firms were made responsible for an employee's first six weeks of sick pay. The introduction of this type of privatization of the disability system, although echoing a similar reform introduced in Great Britain in the mid-1980s, was unprecedented in the Netherlands. It represented a deliberate change in policy intended to encourage firms to provide accommodation, rehabilitation, and continued employment opportunities to workers as an alternative to moving them onto long-term cash benefits. The mandate that firms would bear the full responsibility for sick pay was extended from six weeks to one year in 1996. Despite these reforms, the decline in the Dutch disability recipiency rate stopped in 1997 and began to slowly climb.

In 2002, the Dutch disability system began to phase in the third and most significant set of reforms. These reforms culminated in the establishment of a new disability insurance scheme in 2004-WIA-which replaced the WAO scheme that had been in place since 1967. These systemic reforms fundamentally changed disability policy in the Netherlands. The reforms made work rather than cash benefits the expectation and enforced this by increasing the incentives of both employees and their employers to invest more time and effort in accommodation and rehabilitation following the onset of a disability.

Foremost among the reforms was the extension from one year to two years of the mandate that firms (including small employers) bear full responsibility for employees' sick pay. These changes effectively meant that during the first two years following a health shock, workers were the responsibility of the firm and not eligible for long-term government provided disability benefits. During these two years, employers must allow workers receiving sickness benefits to remain with the firm and can only dismiss employees who refuse to cooperate in a reasonable work-resumption plan.

The reforms also gave firms a list of prescribed rehabilitation and accommodation activities that they (via a private occupational health agency) must provide to workers to assist them in remaining on their job or finding alternative employment. When the two years are complete, workers are allowed to apply for long-term disability benefits, but they are required to provide documentation regarding return-to-work efforts during the two-year period. In 2007, nearly 14 percent of disability insurance claims were returned to employers and the employer continued to be responsible for employing the worker until the claim was processed or the worker had returned to the old or a new job.

Reforms at the front end of the process were accompanied by significant reforms in the longer-term benefit program. All employers were made to pay for the full and permanent disability program through a uniform pay-as-you-go premium rate. Employers also had to pay to fund the publicly run partial disability program, but they could opt out of it by enrolling their workers with a private insurer instead. Either way, employers have to pay experience-rated premiums that cover the first ten years of partial disability benefit receipt. After ten years, benefits are covered by the uniform pay-as-you-go rates that also cover the fully and permanently disabled and the stock of current beneficiaries under the old system. Based on these reforms, the Dutch disability system, long seen as out of control, is now considered by Prinz and Thompson (2009) in their comparison of OECD disability systems as one that has learned from its mistakes and provides an example for other OECD countries to follow. 
While it is still too early to determine the full effect of these policy changes on the Dutch disability beneficiary population, Van Sonsbeek and Gradus (2011) provides the first micro-simulation of the consequences of the post-2002 round of policy changes discussed above. They estimate that the combined impact of the introduction of experience rating together with the introduction of the statutory Gatekeeper Protocol and stricter examinations will reduce the projected long-term number of disability beneficiaries by 600,000 and that the introduction of the new WIA scheme will further reduce that projected number by 250,000 by 2040 , as compared to a "no-change scenario."

\subsection{Sweden}

Like most European nations Sweden has a long-standing first-tier, universal needsbased cash transfer program that provides a guaranteed social minimum income floor to all its citizens. This first-tier protection is funded out of general revenues and is available to everyone who lives or works in Sweden. Although benefits provide minimum income to anyone in need, applicants apply for benefits based on income and particular circumstances, such as disability, parental needs, or old age. Benefits are set nationally and indexed to keep pace with the price level.

Sweden also provides second and third tier benefits. The second tier in Sweden includes unemployment insurance benefits, which include both a mandatory and voluntary component. The mandatory component is paid for by all employers and replaces a minimum fraction of wages for covered workers. The number of weeks covered by unemployment insurance has fluctuated over time but is generally longer than in the U.S. Most individuals also are covered by voluntary unemployment insurance which is negotiated between firms and trade unions. Somewhat uniquely among the countries we review, Sweden also has many private options for unemployment insurance; these may be purchased individually or through an employer.

Sweden provides third tier benefits, including old-age pensions and sickness and disability benefits, through a combination of programs. For those with an earnings history the bulk of the protection is provided based on a social insurance program that, as in the U.S., is financed by statutory employer and employee contributions. Many employers in Sweden also pay into occupational-based insurance and pension programs on behalf of their employees. Participation in these schemes is driven by competitive forces or collective bargaining agreements with unions but a majority of employers in Sweden participate in these programs. See Table 2 for more details about the Swedish disability system.

As in the Netherlands, a key reason for the rapid growth in the Swedish disability program over the 1970s (see Table 1) was the relatively generous benefits that the system provided. That generosity was apparent both in the ease of entry onto the program and the replacement rate of benefits. The first level of protection for Swedish workers with health problems is a sickness benefit. In the 1970s, sickness benefits replaced about 90 percent of expected earnings for individuals with "abnormal physical or mental conditions" that reduced their normal work capacity by at least 25 percent. Workers claiming sickness absence for more than eight days were required to get a certificate from a doctor. This was primarily facilitated by the individual's doctor with no centralized screening or standards. 
After one year, employees still receiving benefits could apply for long-term disability insurance. Workers with functional limitations that caused a reduction in their capacity to perform work commensurate with their job training and work history were eligible for disability benefits. Benefits were awarded for partial (50 percent) and full disability. For those under age 60, benefits included rehabilitation and vocational training. For those 60 and older, beneficiaries were provided income support. Like sickness benefits, disability benefits were very generous replacing the vast majority of expected lost earnings.

Over the course of the 1970s, standards for obtaining long-term disability benefits were also loosened to make it easier for the long-term unemployed to move onto the program. For workers of all ages, unemployment spells of more than one year were added to the list of criteria considered in the disability screening process. For workers over age 60, long-term unemployed became a sufficient condition for moving onto disability benefits, even without a certifiable functional limitation. Similar to the Dutch case, these changes meant that the disability benefit program was increasingly being used as a very generous long-term unemployment insurance program ${ }^{14}$.

Generous benefits and easier access resulted in steady growth in disability recipiency rates over the 1970s and 1980s (Figure 3, Panel D). These features also left the program vulnerable to rapid growth related to the serious recession in the early 1990s. As shown in Figure 3, Panel D, following the foreign exchange crisis in 1990 and ensuing deep recession, disability recipiency rates surged. Policymakers responded by lowering the replacement rates on sickness benefits, making employers pay for the first 14 days of sickness absence, and removing the pure labor market criteria for disability benefits for older workers. With these changes to policy and an improving economy, disability recipiency rates stabilized for most of the rest of the decade. That said, they remained quite high and at a level that policymakers believed unsustainable. As such, additional policy reforms were made throughout the 1990s designed to increase the employer cost of worker sickness absence and increase the threshold for workers applying for sickness and/or disability benefits ${ }^{15}$.

Facing increasing fiscal pressures and a renewal of disability recipiency rate growth (Figure 3, Panel D), in 2000 the Swedish government proposed much more sweeping reforms to the sickness and disability system. Despite considerable opposition from various advocacy groups, significant reforms were put into place over the remainder of the decade. The driving principle behind the reforms was that work support, rather than cash assistance in lieu of work, was the primary goal of disability policy.

This general principle translated into a number of important specific reforms. In 2003, the government merged the sickness benefits and disability systems and began a series of changes to standardize and enforce the administration of these now joint systems. Most notable among them was the centralization of screening processes. Up until this point, certification for sickness benefits had been variable as had disability benefit allowance rates. Although rehabilitation and vocational training were goals, many doctors and regional disability gatekeepers focused on providing income support rather than work retraining. By centralizing the process and developing standardized protocols for granting cash benefits, policymakers were better able to regulate the gatekeepers and enforce the strategy of promoting participation in work before offering cash benefits. Although it is too early to judge the effectiveness, the idea is that this 
standardization will temper the link between regional economic conditions and disability recipiency that had historically been present.

In addition to standardizing the screening process, the merger of the sickness and disability programs forced disability gatekeepers to become actively involved early in the process. By getting vocational and rehabilitation experts involved early, at the sickness benefit stage, policymakers intended to stem the flow of new applicants to the long-term disability program. To aid in this process, sickness benefits were capped at one year, and beneficiaries were evaluated for work ability at 180 days of absence. Only those who could show that they had no capacity to perform any job were allowed to remain on the program for the full year. In addition, employers were required to work with disability administrators to create a rehabilitation plan. And gatekeepers were given the power to demand that employers provide certification about the types of accommodations they made for the worker. These reforms resulted in a decline in the use of sickness benefits and a subsequent decline in the flow of new beneficiaries onto the long-term disability system.

In 2008 the Swedish government undertook an additional series of reforms to its sickness and long-term disability programs (these reforms are detailed in Hartman 2011 and Organisation for Economic Co-operation and Development 2009). These reforms were meant to further curb growth in the rolls and more actively return newly impaired workers to back to the labor market. The 2008 reforms went beyond engaging gatekeepers and employers and focuses on individuals with disabilities. New rules aimed at strengthening the incentives for individuals with disabilities to work and improving their opportunities to do so. The principal reform was the establishment of a new timeline for the provision of rehabilitation services under the sickness absence program with checkpoints closely aligned with assessment of work capacity and a reduction of the cash value of sickness benefits for those who did not return to work. In addition to adding more checkpoints, the reforms also front-loaded the evaluations so that they were being done at 3-, 6-, and 12-month increments. The earlier checkpoints provided rehabilitation, counseling and assessment much closer to the onset of an impairment, when return to work was more likely.

The reforms significantly increased the return to work of new sickness program entrants and reduced their time on the program. In contrast, few of those already on the sickness program when the new reforms were initiated ever returned to work. When their sickness benefits ended they simply moved onto other social assistance programs. These findings provide empirical evidence that early intervention matters. Waiting even one year following the onset of impairment significantly reduces the chance that rehabilitation will result in a return to work. Importantly, these reforms resulted in further reductions in disability recipiency rates in Sweden (Figure 3, Panel D).

Although the disability reforms put in place by the Swedish government late in the 2000s effectively reduced disability recipiency rates in the nation, the reduction came mostly from reductions in new beneficiaries rather than returning existing beneficiaries to work. In recent reforms, policymakers have specifically focused on reducing disability caseloads. For example, in January 2013 the government launched an experiment that allows a large group of existing beneficiaries to return to work without fear of ever losing their right to return to benefits. So far the program has had little impact on the work effort of existing beneficiaries eligible for the program. Although early in the 
experiment the limited impact suggests that returning beneficiaries to the labor market after a long absence is difficult.

\subsection{Great Britain}

Great Britain has substantially reconfigured the way it provides social insurance and social welfare cash transfers over the last four decades. In 1971 it provided first tier universal needs-based cash transfers via its Supplementary Benefit program. It provided somewhat higher second tier cash transfers via its Unemployment Benefit program for those expected to work. Great Britain's major social insurance program for working age people with disabilities between 1971 and 1995 was its Invalidity Benefit (IVB). All those of working age who were deemed unable to work in their usual occupation on grounds of ill health or disability (determined largely by the claimant's family doctor) and who had a record of sufficient social insurance contributions (paid during employment) were eligible, initially for Sickness Benefit (the first 28 weeks) and subsequently for IVB.

Both Sickness Benefit and IVB-proper recipients were counted in the IVB register. Individuals with an insufficient record of social insurance payments were eligible for "credits only" payments (the IVB system would pay their social insurance contributions) generally alongside means-tested Supplementary Benefit payments. This group was also counted in the IVB register.

IVB paid a slightly higher third tier flat rate to beneficiaries, which was more generous than unemployment benefits for longer-duration claimants. Some (generally older recipients with a sufficiently long work history) also received a small earnings-related premium known as the Additional Pension. Even for those receiving this Additional Pension their replacement rates were still considerably less generous than those in the Swedish and Dutch disability systems. This regime was in place throughout the period of slow but steady growth in disability recipiency rates over the 1970s and early 1980s (see Figure 3, Panel B).

The 1980s brought a number of major changes that affected IVB recipiency rates in opposite directions. One change in particular that held back growth during the earlymid-1980s was the introduction of Statutory Sick Pay in 1983, which-like the Netherlands-made employers responsible for paying sickness benefits, in this case for the first 8 weeks of a claim. This was extended to 28 weeks in 1986. These beneficiaries were not counted by the IVB register, so even if this reform did not impact behavior - which seems unlikely given the change to employer incentives - it did remove many shortduration claims from the roll (see Anyadike-Danes and McVicar 2008).

Labor market factors, including recessions in the early 1980s and early 1990s and rapid structural change away from mining and heavy industry throughout the 1980s and into the 1990s, acted in the opposite direction. Indeed the rapid growth in the disability recipiency rates during the latter half of the 1980s and the first half the 1990s has been widely interpreted as a form of hidden unemployment (Figure 3, Panel B). These were applicants with health-related impairments who had lost their jobs and resided in local labor markets characterized by low labor demand, who either moved directly onto IVB or switched to IVB following an unsuccessful period of job search on (less generous) unemployment benefits (see Beatty et al. 2000). Further, echoing the trend in the US, a growing proportion of IVB claims over this period were related to 
hard-to-measure mental illness or muscular-skeletal conditions, despite no explicit change in the medical screening regime for IVB over this period (McVicar 2008).

Both financial and "hassle-avoidance" incentives to shift to IVB from unemployment benefits were intensified with the introduction of Restart in 1987-1988, which imposed compulsory work-focused interviews for long-term unemployment benefits claimants, reduced the generosity of unemployment benefit payments, and introduced a requirement to show evidence of job search activity at fortnightly signing interviews. Huddleston (2000) suggests "there is clear evidence of a 'structural break' around 1987" in moves from unemployment to IVB (for which no such reforms had been introduced), coinciding with the in-step increase in disability recipiency rates.

Another factor likely contributing to growth in the IVB rolls occurred in 1988 when the Income Support program replaced Supplementary Benefits as the primary meanstested social assistance payment for those out of work with insufficient work history to qualify for IVB proper or other insurance-based payments. Although there were various elements to this reform, the key change for our purposes was that those claiming Income Support on grounds of disability, and thus counted in the disability roll, could now receive a higher level of payment (the Disability Premium) than those claiming Income Support on other grounds.

Because yearly increases in IVB fixed rate (since the 1980s), unemployment, and social assistance payment benefits are tied to inflation they have generally declined relative to real wages, hence lowering their real replacement rate even at the bottom of the wage distribution. But for those IVB beneficiaries who were also eligible the Additional Pension this was less the case since their value was tied to real wages. This was especially the case in the recessionary years of the early 1990s when rises in Additional Pension benefits temporarily made IVB more than twice as generous as unemployment benefits for many older recipients (Huddleston 2000).

This period of rapid growth in disability recipiency rates came to an abrupt end in 1995, with a set of major reforms that ended the IVB program and replaced it with the Incapacity Benefit (IB) program for all new beneficiaries. Like other European countries, this reform attempted to slow inflows into the disability benefit systemwhich had been particularly high during the years of rapid growth leading up to 1995 (Anyadike-Danes and McVicar 2008)-rather than reduce the existing stock of beneficiaries. Means-tested beneficiaries of the Income Support program with disabilities continued to receive a Disability Premium and be counted as part of the IB program. But IB was both less generous than IVB (the earnings-related Additional Pension was scrapped for new claimants and payments were made taxable) and most importantly the medical eligibility system was tightened. Medical screening was now carried out by government doctors, working for the relevant agency, rather than family doctors. This type of standardization is similar to that adopted by Sweden in 2006 (although workers' eligibility for up to 28 weeks of Statutory Sick Pay was still determined by family doctors).

The bar was also set higher, moving to an assessment of the claimant's capacity to carry out any work rather than work in their usual occupation ${ }^{16}$. In addition, IB's status as a social insurance payment was blurred in 1999 with the introduction of limited means-testing for new claimants with significant (private) pension income, even those who had made sufficient social insurance payments to be otherwise fully covered for IB 
benefits. There were also further reforms tightening the conditions for unemployment benefit receipt and reducing its generosity over this period, most notably the replacement of the old regime of unemployment benefits with Jobseekers' Allowance in 1996. This tightening of second tier unemployment benefits might in part explain why disability recipiency rolls began to rise again in the late 1990s and early 2000s.

Disability recipiency rates only began to fall again in the mid-2000s coincident with a new set of work-first reforms called Pathways to Work, aimed at slowing the inflow of disability beneficiaries and boosting outflows for those having recently joined the roll. This program was piloted in 2003 and rolled-out nationally beginning in 2005. It made movement onto the IB program (including receipt of social assistance on disability grounds) conditional on attendance at work-focused interviews, with the aim of steering at least some recipients into employment support services and ultimately back into the labor market. It also introduced a 'back to work' bonus payment and provided additional in-work condition-management health support for those returning to employment from IB. Finally, medical assessments (now relabeled Personal Capability Assessments) were brought forward, taking place 3 months into the IB claim rather than 6 months into the claim. Early evaluation evidence from the pilots suggested that Pathways to Work made a significant contribution to falling (local) disability rolls at the time, although the extent to which this was reflected at the national level has subsequently been questioned ${ }^{17}$.

Disability recipiency rates have continued to decline since then, even in the midst of the deep and long-lasting slump in labor demand associated with the Global Financial Crisis. In part this is likely to reflect the inflow-constraining effects of the earlier reforms to disability benefits described above. But there have also been further reforms to disability benefits over the last five years, which are likely to have further restrained growth in the disability roll despite the difficult macroeconomic conditions.

In 2008 the new Employment and Support Allowance (ESA) program replaced IB as well as IS on grounds of disability for new applicants. This new program of insurancebased benefit for those with sufficient work history and means-tested social assistance benefit for those without sufficient work history included a new tougher Work Capability Assessment, with fewer exemptions, in place of the existing system of Personal Capability Assessments (see Sissons 2009). The requirement to attend work-focused interviews introduced under Pathways to Work has been extended into a requirement to engage in workrelated activity for all but the most severely disabled, linked explicitly to payments, with around one quarter of the existing benefit payment made conditional upon compliance. There is also no longer a higher rate of payment for longer-duration claims. Sissons (2009) interprets the lack of growth in disability recipiency rates over the period 2008-2009 as evidence that they have ceased to play a role as a major destination for the hidden unemployed.

In a break with the tradition of reforms largely targeted on inflows (or at least recent joiners) to disability rolls, and echoing similar efforts at activation of existing recipients in Sweden, between 2009 and 2013 existing IB recipients have also been reassessed under the new ESA eligibility criteria. Many have been judged ineligible as a result of medical re-screening under the stricter Work Capability Assessment, although some have since successfully appealed these decisions and others, as was the case in Sweden, have moved onto unemployment benefits rather than into employment. It remains to 
be seen whether the additional activation measures for existing recipients will have any more impact than was the case in Sweden.

\subsection{Australia}

Unlike the other disability programs discussed above whose benefits are at least partly conditional on past contributions, Australia's disability income support program-the Disability Support Pension (DSP) - does not provide benefits based on workers past earnings or even require them to have "paid for coverage". Instead it is most similar to a means-tested guaranteed minimum income program whose benefits are greater than those provided by other Australian welfare or unemployment benefit programs. Hence, DSP is closer in concept to a disability-based welfare program than a traditional social insurance program. However its benefit guarantee is substantially higher relative to average wage earnings in Australia than is the U.S. SSI benefit guarantee relative to average wage earnings in the U.S. In that sense its replacement of lost earnings is closer to what DI pays in the U.S. In both Australia and the U.S. disability program benefits are substantially less generous than those of the Netherlands and Sweden.

Nonetheless the DSP program is susceptible to the same risks to growth discussed in the context of our other countries, since it pays benefits higher than those from other programs and eligibility is based on the malleable concept of disability. While there have been some changes in the DSP income disregard, tax rates, and in its nominal benefit guarantee, over the entire period from 1970 to 2011, the break-even income threshold where DSP benefits go to zero has only increased slightly faster than average wage earnings. Although this represents an overall "loosening" of the income eligibility criteria for DSP, it is not large enough to explain the variations in disability recipiency rates pictured in Figure 3, Panel A.

Cai and Gregory (2004) show that there was little or no trend increase in the level of the DSP benefit guarantee payment relative to average weekly earnings between 1970 and 1999-it rose slightly in the early 1970 s and has since been a relatively constant fraction of average weekly earnings-suggesting that increases in the replacement rate are not an important explanation for DSP growth over the period up to 1999. Moreover, over the first decade of the 2000s the income threshold actually increased more slowly than average earnings, corresponding to a "tightening" of eligibility criteria for DSP and coinciding with a flattening out of the cumulative unadjusted DSP recipiency rates over the period and a slight decline in the cumulative adjusted DSP recipiency rates between 2002 and 2007 (McVicar and Wilkins 2013).

But, DSP has become more generous relative to earnings at the lower end of the earnings distribution, at least over the period from 1993 to 2011, and this may be a more relevant comparison for low-skilled workers with disabilities. For example, over this period, adult full-time weekly earnings at the 10th percentile increased by a factor of just under 2, whereas the maximum DSP payment has increased by a factor of approximately 2.4 (Australian Bureau of Statistics 1994, 2013). Similarly, the level of DSP payments has increased substantially relative to the level of the Australian minimum wage over the period from 2000 to 2011, and particularly from 2008 onwards. The DSP has also become more generous relative to more general income-support payments, most notably unemployment benefit (known as 'Newstart Allowance' (NSA) since 1996), since the mid-1990s. 
Nonetheless it is likely that the major changes in DSP recipiency rates shown in Figure 3, Panel A, are driven by changes in disability eligibility criteria rather than the relative generosity of benefits. This view is supported by work by Cai and Gregory (2004) who suggest that the small drop in DSP recipiency rate between 1980 and 1982 was the result of a tightening of eligibility rules by the administrative authority, which began placing greater emphasis on medical factors and less weight on socio-economic factors, but that this change in approach was largely reversed in 1983, when the Labor Government came to power.

The most important run up in the adjusted DSP recipiency rate occurred in the 1990s (Figure 3, Panel A). Australia experienced its last official and most serious recession in the early 1990s. In 1991, in the midst of this recession, there was a major change in the DSP eligibility criteria. To be eligible for DSP a worker had to be incapable of working more than at 15 per cent capacity. This was increased from 15 per cent (an 85 per cent work impairment standard) to 'no more than 30 hours per week'effectively a 25 per cent impairment standard if a 40-hour work week is considered normal. This effectively changed DSP from a long-term total disability program to a long-term partial disability program with no reduction in benefits. Hence it required DSP gatekeepers to decide if an unemployed worker with a partial (as low as 25 per cent) disability was unemployed because of his or her disability or because of economic conditions in the midst of a period of slow economic growth and high unemployment rates.

It is not surprising that DSP rates increased substantially over this period. While DSP benefits were not significantly greater than first tier social minimum benefits, DSP then provided a somewhat higher and more permanent income floor with no work requirement ${ }^{18}$. Because, as in the U.S., few entrants to DSP leave the program to return to work, such increases in the inflow of beneficiaries during recessions led to increases in disability recipiency rates that lasted over many additional years.

As the Australian economy recovered and then expanded, growth in DSP recipiency rates slowed (Figure 3, Panel A). Although unemployment has ebbed and flowed in Australia since then, the deterioration in employment conditions during the two subsequent worldwide recessions, especially during the Global Financial Crisis, has been less severe in Australia than in the U.S and other OECD countries. Nonetheless DSP recipiency rate growth increased during both worldwide recessions. And since 2008, DSP recipiency rates have increased each year despite a major DSP eligibility change in July 2006 that lowered the work capacity level from no more than 30 hours to no more than 15 hours per week-effectively an increase from a 25 to a 62.5 per cent in the impairment standard.

McVicar and Wilkins (2013) provide a reason for this recent growth. Since 1996 DSP benefit levels-whose growth is indexed to average wage earnings-have grown, both with respect to the minimum wage and with respect to the first tier universal social minimum income guarantee program that is tied to an inflation index. Hence DSP is not only replacing a greater percentage of low skilled workers' wage earnings but is an increasingly attractive alternative to Australia's Newstart Allowance social minimum benefit guarantee. This pattern is similar to the one documented by Autor and Duggan (2003) and Autor et al. (2008) for the U.S.

Cai and Gregory (2004) and McVicar and Wilkins (2013) also argue that reforms to non-DSP welfare payments over the 1990s and 2000s had unintended consequences for 
DSP receipt. Certain types of payments, such as for temporary sickness, were discontinued in the 1990s and-more importantly-over the 1990s and 2000s welfare benefits for the unemployed and for lone parents became increasingly conditional on verifiable job search and participation in active labor market programs, reducing the relative attractiveness of these benefits. Consistent with these changes, and also with the increased relative generosity of DSP, McVicar and Wilkins (2013) show that over the period from 1993 to 2011, receipt of non-DSP welfare benefits by people with disability declined appreciably, but that this was largely offset by the increase in DSP receipt. Thus, welfare reforms that made the benefits for unemployment and lone parents less generous were to some extent thwarted by the shift of significant numbers of beneficiaries from these non-DSP welfare programs to the DSP.

The increased incentives for unemployed low skilled applicants to apply for disability benefits puts additional pressure on DSP gatekeepers to only admit those who are unemployed because their impairment reaches the DSP standard. But because the relationship between impairment and disability is mutable this is hard to do. Thus, in economic downturns, the increased pool of potentially eligible unemployed workers is likely to result in program growth and may have done so despite the increase in eligibility standards in 2006. This suggests that while the tightening of program eligibility rules from a 25 to a 62.5 per cent impairment standard may have had some role in mitigating the rise in the relative generosity of DSP program benefits, it is more likely that it is the strong Australian economy that did not go into recession, rather than a fundamental change in its disability system, that is responsible for the plateauing of DSP recipiency rates over the 2000s reported in Figure 3, Panel A and Table 1. If the economy rather than reforms are responsible, Australia likely remains vulnerable to increases in disability recipiency in the future (for a fuller discussion of this issue, see Burkhauser and Daly 2013).

\section{Conclusion and lessons from reforms in other countries}

In the remainder of this paper we consider how the reform experiences in Australia, Great Britain, the Netherlands, and Sweden can inform U.S. policymakers tasked with ensuring DI's fiscal sustainability.

First and foremost to effectively design policies to curb disability recipiency rate growth, policymakers have to acknowledge why it is growing. A large body of research has shown that in advanced industrialized economies with large and complicated safety nets, both exogenous factors-population demographics, population health, or economywide shocks-and endogenous factors-changes in eligibility rules, benefit replacement rates, or access to other social programs-can influence disability recipiency rate growth. The disability reforms undertaken in the Netherlands, Sweden and Great Britain were possible once these countries acknowledged that changes in behavior rather than changes in health were driving program growth. By recognizing that their policy designs influence behavior and program outcomes, policymakers opened the door to more fundamental disability policy changes.

Importantly, this acknowledgement also allowed policymakers to rethink their national disability scheme's goals and bring them more in line with modern notions of disability. This meant discarding terminology and criteria of incapacity and replacing them with a focus on ability. More than just semantic window dressing the new 
terminology changed people with impairments expectations from dependence on disability benefits based on not working to work. Of course, for some individuals work was not possible, but this increasingly became the exception rather than the norm.

As the previous section demonstrated, each nation implemented reforms slightly differently, but all shared the goal of curbing unsustainable program growth by changing the culture and social expectations of and for people with disabilities and better aligning the incentives embedded in program design with these expectations. The data show the reforms have generally been successful. Although each of the nations recognize their reforms have not been completely successful, from the U.S. perspective these reforms demonstrate that policies matter and provide a relevant starting point for discussions about reforming the U.S. system.

Below we provide the four lessons most relevant to U.S. policymakers.

\section{Lesson 1. Disability does not mean incapacity}

Although disability is frequently thought of as an immutable, health-based condition that limits functionality and prevents the performance of socially expected tasks (such as attending school or working), modern notions of the productive capacity of all people is at odds with this characterization. A more accurate concept of disability, and one embodied in the U.S. Americans with Disabilities Act (ADA) and the World Health Organization's (WHO) International Classification of Functioning, Disability, and Health (ICF), considers disability to be the product of an interactive process between an individual's health conditions and the social and physical environment. In this perspective, disability is neither immutable nor determined solely by health.

Each of the European countries we reviewed embrace this idea. Ensuring that their citizens with disabilities have the opportunity to work in the paid labor market is now a government priority ${ }^{19}$. Key among the findings based on their successful efforts to reduce their disability recipiency rates is that a substantial share of people who were moving onto the long-term cash transfer disability programs were, with reasonable levels of support, able to find or maintain employment. Of course, a subset of workers with disabilities have impairments so severe that work is not possible, but this has proven to be a smaller portion than previously accepted onto these programs. And those now coming onto the rolls are, by demonstration rather than assumption, unable to integrate effectively into the labor market even with appropriate incentives and support ${ }^{20}$. This design offers an important advantage over programs based on categorical determinations of disability that can expand in unintended ways when individuals are incentivized to change their behavior (i.e., attempt or not attempt to work) to become eligible.

The lesson for U.S. disability policy is that the population with disabilities is heterogeneous and many of its members can work. This view is at odds with the current U.S. system in which the Social Security Administration (SSA) requires applicants to demonstrate an inability to perform substantial gainful activity before receiving access to benefits or any other type of support, including work support. Embracing the ideas of many European countries about the work capacity of individuals with disabilities calls for restructuring the U.S. system to bring forward the focus on employment and make long-term cash benefits a last-resort option once rehabilitation and accommodation had failed. 


\section{Lesson 2. Incentives affect behavior}

Once it is recognized that the social and cultural environment faced by individuals with impairments partly determines the extent to which their impairment limits them, it is easy to see that the incentives embedded in policy design can affect outcomes. The important lesson from the reforms in our sample of countries is that it is important to correctly incentivize all actors in the process to attain the outcomes desired.

In the Netherlands, this meant making employers bear more of the direct costs of the program and making employees comply with rehabilitation and retraining in order to maintain benefits. In Sweden this meant standardizing the disability screening process and holding disability gatekeepers accountable for engaging applicants in work rehabilitation plans. Sweden also mandated that employers document how they had attempted to accommodate impaired workers. Finally, reforms focused on making workers comply with the work-first approach by reducing or eliminating benefits to those workers who did not comply with the rehabilitation and accommodation plans. Great Britain has similarly made employers responsible for paying sickness benefits for the first 28 weeks of a claim, has standardized the disability screening process, and has made it increasingly difficult to remain passively on long-term disability benefits without engaging in work-related activity. Reforms have also sought to address financial incentives related to imbalances in replacement rates between disability benefits and other welfare benefits. In Australia, most recently (since 2011) it has meant implementation of a new disability benefit assessment procedure, under which eligibility for benefits typically requires evidence that claimants were unable to obtain employment through vocational rehabilitation or other employment services over a period of up to two years, during which time claimants receive NSA and associated support services.

The lesson for U.S. policymakers is that program incentives affect how people with disabilities and their employers react to, and fare after, the onset of a health impairment. In the U.S., DI is funded from a payroll tax and the federal government is responsible for a great share of the costs associated with providing long-term disability benefits to working-age people with disabilities. Because employers bear no direct responsibility for funding benefits paid to former employees, employers have no direct financial incentive to accommodate and rehabilitate employees who become impaired. Incentivizing employers to make greater investments in accommodation and rehabilitation by creating a scheme that makes employers internalize some or all of the costs of moving employees onto long-term disability could curb DI growth by more effectively aligning incentives. Autor and Duggan 2010 and Burkhauser and Daly 2011 propose two different models for doing this in the U.S.

As the reforms in these countries show, incentives cannot be changed solely for employers. Incentives for people with disabilities and program gatekeepers also need to be aligned with program goals to realize sizeable and lasting reductions in disability recipiency rates.

\section{Lesson 3. Early intervention reduces flows-stocks are harder}

A recurring theme in the experiences of Great Britain, the Netherlands, and Sweden is that reforms focused on early intervention can be very successful at reducing the flow of new beneficiaries onto the program and/or boosting the flow of new beneficiaries off the program. For example, early intervention that coordinated employer actions with 
the employees' particular health shock were critical to keeping impaired workers in the labor force in the Netherlands. Such intervention significantly increased the return to work of impaired workers and reduced time on the sickness or disability program. Evidence from Sweden shows that waiting even one year following the onset of impairment significantly reduces the chance that rehabilitation will result in a return to work. Evidence from Great Britain suggests that bringing medical screening forward can help to control program growth.

In contrast, none of these countries, nor Australia, has been successful to date at moving existing longer-term beneficiaries back into the labor market, although the process of re-screening and seeking to activate existing longer-term beneficiaries in Great Britain has only recently begun. Across all countries, once enrolled on disability benefits for more than a few months, only a small fraction of recipients return to work. Even when strict time limits are put in place, as in the case of Sweden, movement off the disability system for longer-duration beneficiaries is difficult. Even when it is done, most frequently it results in a shift to another public program rather than into employment.

These experiences have several implications for U.S. policy discussions. First, the fact that most current DI recipients do not work is not evidence that they would have been unable to work if given alternative policy treatments (e.g., timely accommodation and rehabilitation). Indeed, the marked difference in outcomes between those given early versus later employment-oriented services in the Netherlands and Sweden shows that in a system oriented towards long-term cash benefits rather than work, many of those with residual work capacity will never return to work.

The experiences in these countries also call into question the viability of ongoing attempts to gain control of the U.S. DI rolls by funding additional continuing disability reviews or enhancing post-entry rehabilitation or job training programs like Ticket-toWork. While such programs have merits, the experiences in Sweden tell us that these efforts will fall short of bringing growth in the rolls down to sustainable levels.

Finally, the reforms and outcomes in these nations show the difficulties of focusing policy reforms on current beneficiaries-a practice SSA is forced to follow by rules requiring SSA-collected funds to be focused on current program recipients. This suggests that eliminating this rule and allowing SSA to focus its energies on workers with health-based work limitations who are trying to decide whether to stay on the job or apply for benefits will likely do more to curb DI growth.

\section{Lesson 4. Hurdles to reform in the U.S. are surmountable}

Despite this growing body of evidence that structural reforms to long-term cash disability programs can curb program growth and potentially improve outcomes for those with health-based impairments, the political coalition necessary to achieve fundamental disability policy reform has been slow to evolve in the U.S. So what are the hurdles? There are several including a number of concerns raised by supporters of the current system. (See Reno and Ekman 2012 for a summary of these arguments.)

One issue raised in response to proposals for fundamental DI reform is that these benefits, while not especially generous, are essential to keeping millions of disabledworker beneficiaries out of poverty. The evidence from Europe shows that this is a very static view which assumes that in the absence of benefits, individuals with disabilities would remain out of the labor market, dependent on other forms of public or private 
assistance for support. European disability reforms over the last decade provide plausible evidence that increased employment will occur when pro-work policies replace policies that have had the opposite effect. Their reform experience shows that a significant number of people with disabilities, who would otherwise have moved onto longterm cash benefits, were able, with reasonable levels of support, to return to work. While it is always the case that tightening the criteria for disability benefits runs the risk of denying disability benefits to those who will not be able to find work, on balance the European experience suggests that reasonable pro-work policies will both substantially reduce disability recipiency rates and increase the employment of those who would otherwise have been on the long-term disability rolls.

Nonetheless it is the case that fundamental DI reform could worsen the already precarious economic position of some people with disabilities. But this should be put the context of what has been happening to the overall well-being of working age people with disabilities in the U.S. Over the past 25 years the household incomes of Americans with disabilities have stagnated relative to other working-age people. This is associated, in part, with the near continuous decline in their employment.

Our reading of the European evidence is that when programs are designed to award cash transfers in lieu of work, employment falls. In contrast, when programs are designed to encourage work and award transfers only when work clearly is not possible, employment rises. Since work generally leads to increased income, especially when public policies make work pay, efforts to promote work among those with disabilities can produce positive outcomes.

The most important lesson though, is that by not working, long-term disability beneficiaries will over time slip further and further behind the rest of the working-age population, whose employment allows them to benefit from increased economic growth.

A final concern is that programs like DI are especially important in economic downturns where individuals with limited work capacity are not only more likely to be laid off but less likely to find a new job. Past experience of European countries, especially The Netherlands, which intentionally or unintentionally used this logic to turn their long-term disability programs into more general unemployment programs, suggests that it can be a very expensive and ultimately ineffective policy decision. Indeed, many European nations continue to struggle to regain control over their disability systems which for many decades have been used as long-term unemployment insurance programs. A key message from the European experience is that explicitly divorcing longterm "unemployability" insurance from disability insurance is critical to effectively targeting resources towards both populations.

Together the experiences of other nations suggest that it is possible to balance the competing goals of providing social insurance against adverse health shocks during working-age and maximizing the work effort of all working-age adults with and without disabilities. Past disability policies in both the United States and other OECD countries have focused more on the former than the latter, resulting in rapid growth in disability transfer populations that outpaced growth in the economy. Efforts to shift to more pro-work policies over the last decade in Europe suggest that fundamental disability reforms, if done well, can lower projected long-term costs for taxpayers, make the job of disability administrators less difficult, and importantly, improve the short- and long-run opportunities of people with disabilities. 


\section{Endnotes}

${ }^{1}$ In a recent paper, Pattison and Waldron (2013) argue that population growth explains the bulk of the rise in disability recipiency in the U.S. In this paper we remove the influence of population growth and consider the factors that explain the remaining rise in the program. Since population growth alone would not put additional financial pressure on the system, knowing these other factors is critical to policymakers tasked with putting the system back on sustainable financial footing.

${ }^{2}$ The U.S. disability recipiency rate only includes beneficiaries receiving DI. Although policymakers treat Supplemental Security Income (SSI) and DI as separate programs, Burkhauser and Daly (2011 and 2013) argue that for the purpose of evaluating the role of disability benefits in the U.S. they should be combined. When SSI-disabled adults and DI program beneficiaries are combined, the level of the U.S. disability recipiency rate is higher, but the patterns over time are roughly the same. See for instance Burkhauser and Daly 2013, Figure 2.

${ }^{3}$ The fiscal burden of disability programs comes from the fact that beneficiaries receive income support and they generally do not contribute to the tax base since they are largely out of the labor force.

${ }^{4}$ Disability caseloads data are made public with a considerable lag in some countries. Hence we can't fully document how the Global Financial Crisis affected recipiency rates in all countries.

${ }^{5}$ Some of the difference across countries relates to the age structure of the population. Older populations report lower rates of good health than younger populations. Remaining differences likely owe to reporting differences that are idiosyncratic to each country (see Van Soest et al. 2011).

${ }^{6}$ The fact that adjusting for demographics and the entry of women into the labor force in the U.S. explains only a fraction of the overall growth in disability recipiency rates is consistent with research by Duggan and Scott 2009 and Daly et al. 2013. The characterization of the Chief Actuary of the Social Security Administration (see Goss 2013) contrast with this view, but this owes to the fact that they decompose growth in disability caseloads rather than disability recipiency rates. As noted in footnote 1 , we believe this approach is less informative to policymakers.

${ }^{7} \mathrm{We}$ are not the first to make this point. The Organization for Economic Co-operation and Development (2010) summary of disability program growth across OECD nations concludes that policy rather than population characteristics are behind the rapid expansion of disability benefit receipt in most nations. The point is also emphasized by Autor and Duggan 2010 and Burkhauser and Daly 2011, 2012.

${ }^{8}$ There is no clear consensus on the most appropriate conceptualization of disability, although the most widely used is the World Health Organization's (WHO) International Classification of Disability, Health, and Functioning (World Health Organization 2001).

${ }^{9}$ SSI is similar in design to Australia's Disability Support Pension (DSP) and the Dutch categorical disability-based welfare program (Wajong) but its income guarantee level is substantially lower than either.

${ }^{10}$ The SSI aged and disabled adults programs share the same categorical eligibility criteria applied for the earnings based retirement or Old-Age Insurance (OAI) and Disability Insurance (DI) programs. Individuals with sufficiently low earnings records may jointly qualify for OAI and SSI aged benefits and for DI and SSI 
disabled adult benefits. This said, these programs are generally treated separately by policymakers.

${ }^{11}$ See Berkowitz and Burkhauser 1996 for more discussion of these changes and their effects.

${ }^{12}$ Autor and Duggan (2006) argue that under these new eligibility standards, DI is a form of "unemployability" insurance in which individuals who have limited employment options can find some way to qualify. They offer the example of individuals removed from the rolls in 1996 when drug and alcohol addiction were removed from qualifying impairments. Autor and Duggan (2010) cite research by the (Lewin 1995, Policy evaluation of the effect of legislation prohibiting the payment of disability benefits to individuals whose disability is based on drug addiction and alcoholism: Unpublished report. $1995,1998)$ showing that two-thirds of those removed from the rolls re-qualified based on some other impairment.

${ }^{13} \mathrm{~A}$ longer version of this summary of the Dutch system can be found in Burkhauser and Daly 2011.

${ }^{14}$ Econometric studies of the Swedish system support this view. See for example Rebick 1994; Larsson 2002.

${ }^{15}$ The Swedish government made numerous changes to sickness benefit replacement rates, the number of days the employer paid for employee sickness absence, and the number of days the worker had to wait before receiving sickness benefits (Andren 2003). In addition, policymakers removed most of the special allowances for disability insurance afforded to unemployed and older workers Jonsson et al. 2011.

${ }^{16}$ Although what was assessed in practice was the claimant's capacity to carry out a series of routine tasks (Beatty and Fothergill 2005).

${ }^{17}$ For further details see Adam et al. (2010) and National Audit Office (2010).

${ }^{18}$ There is no tier two unemployment insurance benefit program in Australia. Rather, unemployed workers are covered by a tier one universal minimum benefit, now called the Newstart Allowance. Benefit levels, like in SSI, are need-based and do not require past work experience. However, recipients are expected to return to work.

${ }^{19}$ See OECD 2003 and Bernd et al. 2004 for a discussion of this transformation in disability policy goals.

${ }^{20}$ Importantly, in Great Britain the assumption is that with appropriate support the majority of individuals with disabilities can perform some type and amount of work.

${ }^{21} \mathrm{We}$ use the following age groups for men and women (14 total demographic groups): $20-29,30-39,40-44,45-49,50-54$ 55-59, and 60-64. For the Netherlands age categories are decomposed as follows: $15-24,25-34,35-44,45-54,55-64$.

\section{Additional file}

Additional file 1: Appendix A. Data description and sources. Appendix B. Decomposing the disability recipiency rate. 
Netherlands, Marten Palme and Lisa Laun for data on Sweden, and Benjamin Bradshaw for excellent research assistance.

Disclaimer: This paper was submitted to the IZA Journal of Labor Policy's call for papers on "Social Security Disability Benefits: Finding Alternatives to Benefit Receipt." Two special editors, David Wittenburg and Gina Livermore, were sponsored by the University of New Hampshire's Rehabilitation, Research, and Training Center on Employment Policy and Measurement, funded by the U.S. Department of Education (ED), National Institute on Disability and Rehabilitation Research (cooperative agreement no. H133B100030). Their comments do not necessarily represent the policies of ED or any other federal agency (Edgar, 75.620 (b)). The authors are solely responsible for all views expressed. Responsible editor: Gina Livermore

\section{Author details}

${ }^{1}$ Cornell University and University of Melbourne, Cornell and Melbourne, Australia. ${ }^{2}$ Federal Reserve Bank of San Francisco, San Francisco, USA. ${ }^{3}$ Queen's University-Belfast, Belfast, UK. ${ }^{4}$ University of Melbourne, Melbourne, Australia.

Received: 22 October 2013 Accepted: 7 January 2014

Published: 20 Feb 2014

\section{References}

Adam S, Bozio A, Emmerson C (2010) Reforming Disability Insurance in the UK: Evaluation of the Pathways to Work programme. Institute for Fiscal Studies, London

Andren D (2003) Sickness-Related Absenteeism and Economic Incentives in Sweden: A History of Reforms. www.cesifo-group. de/DocCIDL/dicereport3-03-reform-models-3.pdf (last accessed October 18, 2013)

Anyadike-Danes M, McVicar D (2008) Has the boom in Incapacity Benefit claimant numbers passed its peak? Fisc Stud 29(4):415-434

Australian Bureau of Statistics (1994) Distribution and Composition of Employee Earnings and Hours, Australia 1993, Cat. no. 6306.0. ABS, Canberra

Australian Bureau of Statistics (2013) Employee Earnings and Hours, Australia, May 2012, Cat. no. 6306.0. ABS, Canberra

Autor DH, Duggan MG (2003) The rise in disability recipiency and the decline in unemployment. Quart J Econ 118 (1):157-205

Autor DH, Duggan MG (2006) The growth in the Social Security disability rolls: A fiscal crisis unfolding. J Econ Perspect 20:71-96

Autor DH, Duggan MG (2010) Supporting Work: A Proposal for Modernizing the U.S. Disability Insurance System. The Hamilton Project and Center for American Progress, Washington, DC

Autor DH, Katz LF, Kearney MS (2008) Trends in US wage inequality: Revising the revisionists. The Review of Economics and Statistics 90(2):300-323

Beatty C, Fothergill S (2005) The diversion from 'unemployment' to 'sickness' across British regions and districts. Reg Stud 39:837-854

Beatty C, Fothergill S, Macmillan R (2000) A theory of employment, unemployment and sickness. Reg Stud 34:617-630

Berkowitz ED, Burkhauser RV (1996) A United States perspective on disability programs. In: Aarts LJM, Burkhauser RV, de Jong PR (ed) Curing the Dutch disease: An international perspective on disability policy reform. Avebury, Ashgate Publishing Ltd, Aldershot, Great Britain, pp 71-92

Black D, Daniel K, Sanders S (2002) The impact of economic conditions on participation in disability programs: Evidence from the coal boom and bust. Am Econ Rev 92:27-50

Burkhauser RV, Daly MC (2011) The Declining Work and Welfare of People with Disabilities: What Went Wrong and a Strategy for Change. AEl Press, Washington, DC

Burkhauser RV, Daly MC (2012) Social Security Disability Insurance: Time for fundamental change. J Policy Anal Manage 31(2):454-461

Burkhauser RV, Daly MC (2013) Is Australia One recession away from a disability blowout? Lessons from other OECD countries. Aust Econ Rev 46(3):357-368

Cai L, Gregory R (2004) Inflows, outflows and the growth of the Disability Support Pension (DSP) program. Aust Soc Policy 2002-03:121-143

Daly M, Lucking B, Schwabish J (2013) Explaining the rapid growth in Social Security Disability Insurance rolls. Federal Reserve Bank of San Francisco, San Francisco, California

Duggan M, Scott I (2009) Why Are the Disability Rolls Skyrocketing? The Contribution of Population Characteristics, Economic Conditions, and Program Generosity. In: David Cutler and David Wise, Health at Older Ages: The Causes and Consequences of Declining Disability among the Elderly. University of Chicago Press, Chicago, IL

Goss S (2013) Testimony by steve goss, chief actuary, social security administration before the house committee on ways and means, subcommittee on social security. March 14:2013

Hartman L (2011) "Swedish Policies for the Disabled: What Do We Know About the Effects?" Mimeo, prepared for the "Labour Activation in a Time of High Unemployment" November 13-15, 2011, hosted jointly by the University of Maryland and the OECD. http://umdcipe.org/conferences/LaborActivationParis/Papers/Laura\%20Heartmans\%20draft \%20paper_11_1108.pdf, last accessed October 18, 2012

Huddleston T (2000) Explaining the growth in the number of people claiming Incapacity Benefits. Department for Work and Pensions, London

Jönsson L, Palme M, Svensson I (2011) Disability Insurance, Population Health and Employment in Sweden (No. w17054). National Bureau of Economic Research

Larsson L (2002) "Sick of being unemployed? Interactions between unemployment and sickness insurance in Sweden", Working paper 2002:6. Institute for Labour Market Policy Evaluation (IFAU), Uppsala

Lewin VHI (1995) Labor market conditions, socioeconomic factors and the growth of applications and awards for SSDI and SSI disability benefits. Final Report. The Office of the Assistant Secretary for Planning and Evaluation, U.S. Department of Health and Human Services and the Social Security Administration, Washington DC 
Maestas N, Mullen KJ, Strand A (2013) Does disability insurance receipt discourage work? Using examiner assignment to estimate causal effects of SSDI receipt. Am Econ Rev 103(5):1797-1829

Marin B, Prinz C, Queisser M (2004) Transforming disability welfare policies. Ashgate

McVicar D (2008) Why have UK disability benefit rolls grown so much? J Econ Surv 22:114-139

McVicar D, Wilkins R (2013) Explaining the growth in the number of recipients of the Disability Support Pension in Australia. Australian Economic Review 46(3):345-356

National Audit Office (2010) Support to incapacity benefits claimants through Pathways to Work. National Audit Office, London Organization for Economic Co-operation and Development (2003) Transforming Disability into Ability. OECD, Paris. http://www.keepeek.com/Digital-Asset-Management/oecd/social-issues-migration-health/transforming-disabilityinto-ability_9789264158245-en\#page1t

Organisation for Economic Co-operation and Development (2009) Sickness, Disability and Work: Keeping on Track in the Economic Downturn—Background Paper. OECD, Paris. viewed May 2013, www.oecd.org/dataoecd/42/15/ 42699911.pdf

Organization for Economic Co-operation and Development (2010) Sickness, Disability and Work: Breaking the Barriers: A Synthesis of Findings across OECD Countries. OECD, Paris. viewed March 2012, http://www.oecd-library.org/socialissues-migration-health/sickness-disability-and-work-breaking-the-barriers_9789264088856-en

Pattison D, Waldron H (2013) Growth in New Disabled-Worker Entitlements, 1970-2008. Social Security Bulletin 73(4):25

Prinz C, William T (2009) Sickness and Disability Benefit Programmes: What is Driving Policy Convergence. International Social Security Review, Special Issue: Policy learning and social protection 62 (October/December), pp 41-61

Rebick M (1994) Social security and older workers' labor market responsiveness: the United States, Japan and Sweden. In: Blank R (ed) Social Protection versus Economic Flexibility: Is There a Trade-Off? University of Chicago Press, Chicago

Reno VP, Ekman LD (2012) Disability insurance is part of the solution, not a cause of work disability: response to Burkhauser and Daly. J Pol Anal Manage 31:471-474. doi: 10.1002/pam.21621

Rupp K, Stapleton D (1995) Determinants of the growth in the Social Security Administration's disability programs: An overview. Soc Secur Bull 58:43-70

Sissons P (2009) Welfare reform and recession: past labour market responses to job losses and the potential impact of Employment Support Allowance. People Place Pov 3(3):171-182

Social Security Administration (2013a) How You Earn Credits. Washington, DC. viewed May 2013, http://www.ssa.gov/ pubs/EN-05-10072.pdf

Social Security Administration (2013b) The 2013 Annual Report of the Board of Trustees of the Federal Old-Age and Survivors Insurance and Federal Disability Insurance Trust Funds. Washington, DC. viewed May 2013, http://www. ssa.gov/oact/tr/2013/tr2013.pdf

Stapleton D, Coleman K, Dietrich K, Livermore G (1998) Empirical analyses of DI and SSI application and award growth. In: Rupp K, Stapleton D (ed) Growth in disability benefits. W.E. Upjohn Institute for Employment Research, Kalamazoo, Michigan, pp 31-92

Van Soest A, Tatiana A, Arie K, James PS (2011) Self-Reported Disability and Reference Groups. NBER Chapters. In: Investigations in the Economics of Aging. National Bureau of Economic Research, Inc, pp 237-264. http://ideas. repec.org/h/nbr/nberch/12441.html, http://ideas.repec.org/s/nbr/nberch.html

Van Sonsbeek JM, Gradus R (2011) 'Estimating the Effects of Recent Disability Reforms in The Netherlands', Tinbergen Institute Discussion Papers 11-121/3. Tinbergen Institute

World Health Organization (2001) International Classification of Disability, Health and Functioning. WHO, Geneva, Switzerland

10.1186/2193-9004-3-4

Cite this article as: Burkhauser et al: Disability benefit growth and disability reform in the US: lessons from other OECD nations. IZA Journal of Labor Policy 2014, 3:4

\section{Submit your manuscript to a SpringerOpen ${ }^{\circ}$ journal and benefit from:}

- Convenient online submission

- Rigorous peer review

- Immediate publication on acceptance

- Open access: articles freely available online

- High visibility within the field

- Retaining the copyright to your article

Submit your next manuscript at $\boldsymbol{\nabla}$ springeropen.com 